\section{The response of remittances inflows to asymmetric oil price shocks in Egypt

\author{
Mohamed Samir Abdalla Zahran
} \\ Department of Economics and Public Finance, Menoufia University Faculty of Commerce, Shebin El-Kom, Egypt}

Response of remittances inflows

\begin{abstract}
Purpose - The purpose of this paper is to explore and analyse the dynamic relationship between remittances inflows of Egyptians working abroad and asymmetric oil price shocks.

Design/methodology/approach - This study uses a vector autoregressive (VAR) model to explain the impulse response functions (IRFs) and the forecast error variance decomposition (FEVD). The rationale behind using these tools is its ability to examine the dynamic effects of our variables of interest.

Findings - The impulse response functions confirmed that remittance inflows have various responses to asymmetric oil price shocks. For instance, inflowing remittances increase in response to positive oil price shocks, while it decreases in response to negative oil price shocks. Also, the results indicate that the responses are significant in the short and medium-run and insignificant in the long run. The magnitude of these responses reaches its peak or trough in the third year. Further, the variance decomposition reveals that oil price decreases are more influential than oil price increases.

Originality/value - This means that remittances inflows in Egypt are pro-cyclical with oil price shocks. That explained by the fact that more than one-half of those remittances sent from GCC countries where real economic growth is very pro-cyclical with the oil prices. This empirical assessment will help policymakers to determine the behaviour of remittances and highlights the impact of different kinds of oil prices shocks on remittances. Unlike the little existing literature, this study is the first study applied the VAR model using a novel dataset spanning 1960-2016.
\end{abstract}

Keywords Remittances, Oil price shocks, Egypt, VAR modelling

Paper type Research paper

\section{Introduction}

In recent years, international migration is becoming a sharply increasing global trend. The international migrants' numbers increased from 175 million in 2000 up to 258 million in 2017, according to the United Nations. It means a 47 per cent increase compared to 2000. This increasing trend of migration is accompanying by a steady increase in money transfers

(C) Mohamed Samir Abdalla Zahran. Published in Review of Economics and Political Science. Published by Emerald Publishing Limited. This article is published under the Creative Commons Attribution (CC BY 4.0) licence. Anyone may reproduce, distribute, translate and create derivative works of this article (for both commercial and non-commercial purposes), subject to full attribution to the original publication and authors. The full terms of this licence may be seen at http://creativecommons.org/licences/by/4.0/legalcode

The author sincerely thank the German Academic Exchange Service (DAAD) for providing him a full scholarship for a master programme at Philipps-Universität Marburg in Germany. The author also wish to express his gratitude to his master thesis supervisor, Professor Mohammad Farzanegan, for his encouragement and support. Finally, the author thank the anonymous referees for their useful comments.
Received 20 January 2019 Revised 11 July 2019 Accepted 27 August 2019 
from migrants to their families in home countries, so-called remittances (Asatryan et al., 2017).

Goldberg and Levi (2008) refer to remittances as capital transfers from one country to another made by migrants who stay abroad for more than one year. Remittance flows have attracted much attention in research and policies applications because of their scale and properties (Lueth and Ruiz-Arranz, 2006). According to the World Bank, inflowing remittances to low- and middle-income countries (LMICs) reached $\$ 529 \mathrm{bn}$ in 2018 and are likely to reach $\$ 550 \mathrm{bn}$ in 2019 . That massive size of remittances motivates governments all over the world to pay focused attention to remittances and to analyse its behaviour as high policy interest (IMF, 2009).

Besides its massive size, remittance flows are stable and less volatile than other sources of external financing for developing countries such as private capital flows and foreign direct investment (Vargas-Silva, 2006; Beck and Peria, 2011). That makes inflowing remittances to have substantial development impacts. For instance, it helps to reduce poverty and increase income prospects for households. That, in turn, influences the household's consumption and savings behaviour. So, the better remittances are understood, the better policies and regulations will be designed (Veeramoothoo, 2009).

For Egypt, remittances are of vital economic importance. It is a primary stable source of foreign currency for the economy namely the US\$ and an external source of financing. Unlike the significant decline in all sources of foreign currency since the financial crisis in 2008 and the 2011 revolution, remittances inflows have increased significantly rising from $\$ 8.3 \mathrm{bn}$ in 2009 to $\$ 18.3 \mathrm{bn}$ in 2014 with a more stable pattern than FDI and foreign aid. According to the IMF and World Bank, in 2016, remittances inflows to Egypt from the Gulf Cooperation Council (GCC)[1] states were US\$16.6bn, and it was representing 4.8 percentage of gross domestic product (GDP) in Egypt. Thus, remittances compensate for the sharp drop in foreign currency sources.

However, the stability of inflowing remittances in Egypt is a critical issue that needs a regular investigation for two reasons. First, remittance flows to the MENA region driven by inflows to Labour Abundant countries (Farzanegan and Hassan, 2016). That makes Egypt the top recipient of remittances in the MENA region. Second, the Egyptian economy is dependent on remittances inflows which mainly sent from the Gulf region. The largest source of remittance flows from GCC oil-exporting rich-countries exceed 70 per cent of total remittance inflows to Egypt and accounts for around 5 per cent of its GDP in recent years. In these countries, the population is less, and the economic activities are highly dependent on oil rents. So, the substantial economic spillovers of global oil price changes likely include significant effects on remittances. Hence, oil prices shocks can affect the steady trajectory of remittances inflows in Egypt.

Despite the importance of remittances, little research exists on the relationship between oil price and inflowing remittances. In the literature, there are mixed results. Most of the studies find that remittances react positively to oil price shocks. While others showed a negative or insignificant relationship between oil price and remittance flows. They used different methods such as ordinary least squares (OLS) regressions, instrumental variables (IV) estimations and vector error correction models (VECM).

This paper examines the response of remittances inflows in Egypt to asymmetric oil price shocks. It contributes to the current literature on oil prices impacts on remittances in two ways. First, we apply a VAR model to explain the impulse response functions (IRF) and the forecast error variance decomposition (FEVD). Second, it uses a novel dataset spanning 1960-2016 on Egypt. The findings will help policymakers to determine the behaviour of remittances and highlight its sensitivity to various oil price shocks. 
The paper proceeds as follows: in Section 2, we review the existing literature that covers the relationship between remittances and oil prices. Section 3 shows an overview of workers' remittances inflows in Egypt. Section 4, we discuss the data and methodology. Then in Section 5, the empirical findings and policy implications are presented. Finally, Section 6 summarises the conclusions.

\section{Literature review}

This section discusses the theoretical background and presents the relevant literature concerning remittances and oil price shocks. In particular, this section segmented into two parts. In the first part, we outline and discuss the theoretical underpinnings relative to remittances and oil price shocks. While the second part reviews the most recent literature related to the context of this study.

\subsection{Theoretical model}

The theoretical dimensions are best described by Vargas-Silva (2006) and Hagen-Zanker and Siegel (2007). They discussed the determinants of remittances and covered the motivations to remit, while Sonmez (2016) analysed the different effects of oil price shocks. In this section, first, we identify the determinants of remittances. Second, we discuss the macroeconomic effects of oil price shocks by explaining two theoretical economic tools: ISLM model and the supply-demand framework. Finally, we analyse the transmission channels through which oil price shocks can affect remittances inflows.

2.1.1 The determinants of remittances. The fundamental theory of the new economics of labour migration presents many determinants of remittances. At the micro-level, low money-transfer costs are likely to account for the bulk of unexplained remittance growth (Beck and Peria, 2011; Canas et al., 2007; Hagen-Zanker and Siegel, 2007). Also, the number of migrants plays a significant role in determining the volume of remittances. Moreover, the causes of migration, migrant's labour market earnings level, the strength of their bonds to the home country and the time spent at the destination consider significant determinants of remittance behaviour (Niimi et al., 2009; Canas et al., 2007; Hagen-Zanker and Siegel, 2007). Other determinants are remitter characteristics such as gender, age, education level, marital status, where spouse lives, number of children, earnings per week, have a bank account, has health insurance and migration cost (McCoy et al., 2007).

On the macro-level, there are many factors that affect the volume of remittances such as the economic situations in the origin and the host countries, the interest rate, the ratio of expatriates to population, institutional quality, and the real exchange rate (Singh et al., 2009; Faini, 1994; Rana and Hashmi, 2015). For instance, any devaluation or appreciation of host countries currency can significantly influence the inward remittances. Moreover, the financial sector development positively affects the remittance inflows (Singh et al., 2009). Further, there are other factors including the migration of highly skilled workers, consumer price index, age dependency ratio, political rights, government expenditure, population and unemployment (Rana and Hashmi, 2015; Veeramoothoo, 2009; Gupta, 2006). Therefore, we can flexibly justify the choice of the selected variables in our empirical model in the next section by referring to Singh et al. (2009).

2.1.2 The macroeconomic effects of oil price shocks. There are different types of oil price shocks definitions. Net Oil Increase Model (NOI) is an oil price shock that refers to the difference between the current oil price and the maximum prices in the past 4 years or 12 quarters (Hamilton, 1996). If that difference is positive, then there is price volatility, but if the difference equals to zero, then there is no price volatility. It means that Net Oil Increase Model mainly concentrates on the volume of change and how significant are the changes in 
oil prices by looking at the net oil price changes over a one-year and three years. However, other asymmetric definitions distinguish between positive and negative oil price changes (Hamilton, 1983; Mork, 1989; Farzanegan and Markwerdt, 2009). They defined oil price changes, where (roilpt) is the log of real oil price in time $t$, as follows:

$$
\begin{aligned}
& \Delta \operatorname{roil} p_{t}^{+}=\max \left(0,\left(\operatorname{roilp}_{t}-\operatorname{roil}_{t-1}\right)\right) \\
& \Delta \operatorname{roilp}_{t}^{-}=\operatorname{man}\left(0,\left(\operatorname{roilp}_{t}-\operatorname{roil}_{t-1}\right)\right)
\end{aligned}
$$

Furthermore, another form of non-linear transformation of real oil prices uses the percentage change over the previous year's maximum. For example, how much the oil price of the current quarter exceeds the value of the preceding four quarters' peak (Hamilton, 1996).

$$
\begin{aligned}
& \operatorname{noil}_{t}^{+}=\max \left[\left(0,\left(\operatorname{roil}_{t}\right)-\max \left(\left(\operatorname{roil}_{t-1}\right), \ldots,\left(\operatorname{roil}_{t-4}\right)\right)\right]\right. \\
& \operatorname{noilp}_{t}^{-}=\min \left[\left(0,\left(\operatorname{roil}_{t}\right)-\min \left(\left(\operatorname{roil}_{t-1}\right), \ldots,\left(\operatorname{roil}_{t-4}\right)\right)\right]\right.
\end{aligned}
$$

Also, there are other types of oil price shocks coming from decomposing fluctuations in oil prices into three components: an oil supply shock, a global oil demand shock, and a precautionary oil-specific demand shock (Kilian, 2009a, 2009b). Thus, an oil price shock is either a positive shock or a negative shock. A positive shock means a sharp, unexpected increase in oil prices while a negative shock refers to an unanticipated drop in oil prices. For instance, a negative oil supply shock refers to three consequence declines in oil supply. The oil price increase is up to a point related to supply shortage while the causes of oil price drop segmented into two parts. First, supply is outpacing demand due to new oil exporter countries and oil shale production. Second, simultaneous oil demand decreases because of the slowdown in the growth of the global economy and the growing trend towards sustainable clean alternative energy.

In brief, we will discuss two main theoretical economic tools intuitions: (IS-LM)[2] model and the supply-demand framework. First, the IS-LM model explains the theoretical dynamics of how exogenous oil price shocks affect the output in an oil-importing economy. A production function, with three inputs: capital, labour and oil as an exogenous variable, explains the effects of oil shocks. Positive oil price shocks lead to exogenous increases in imports that shift the IS curve to the left and cause decreases in GDP. That is not only due to the decline in consumer's expenditures but also because of the reduction of public and private spending on planned investment.

In the case of positive oil price shocks, on the fiscal policy side, the government reduced taxes and increased its spending to increase consumer's disposable income. So, the IS curve will partially shift to the right to offset the output deterioration. Therefore, an increase in government spending has a positive effect on the output as the Keynesian, and standard neoclassical models predict (Sonmez, 2016). While on the monetary policy side, the central bank action will depend on inflation expectations. It can intervene by increasing the money supply that in turn shifts the LM curve to the right to stimulate aggregate demand in a try to increase output. Thus, an oil price increase will make the industry and production process of goods costlier, and that produces a recession (Finn, 2000).

Second, the framework of supply and demand side effects became another mechanism that explains the impact of oil price shocks on other macroeconomic variables (Adebiyi et al., 2009). The impact of oil price shocks depends on whether the source of oil price fluctuations 
originates from an oil supply shock, a global aggregate demand shock or an oil-specific demand shock (Kilian, 2009a, 2009b). The combined impact of supply and demand could lead to higher inflation and reduced real output (Ran et al., 2010). As for the supply side, an oil supply increase implies that if the oil goes down, then the output should go up. However, if an oil increase brings about a recession, then an oil price decline should induce an economic boom and vice versa. For instance, an exogenous negative oil supply shock will lead to lower productivity; thus directly the output will be reduced.

On the demand side, an oil price increase reduces the purchasing power of consumers. It makes a substitution of consumption and aggregate demand dropping. That will increase the overall price level, given the Keynesian assumption of rigid wages and will reduce employment. That is due to the reduction in real output because producers will be motivated to substitute less energy intensive capital for more energy intensive capital (Ran et al., 2010). In contrast, an oil price decline is expected to produce an economic boom (Hamilton, 2003).

2.1.3 How oil price shocks theoretically affect remittances inflows. Oil price shocks theoretically affect remittances outflow in oil-rich countries through two transmission channels (Figure 1). The first channel is concerned with the effects of oil price shocks on output, investment, and consumption (direct effect). The second transmission channel is concerned with oil price effects on inflation and unemployment. It investigates whether changes in real oil prices transmitted through real government spending impact unemployment. Thus, that in turn impact remittances outflows from host countries (indirect effect).

On the one hand, oil price shocks in host countries affect foreign worker's remitting behaviour through its direct impact on consumption, investment, and production. The consumer prefers precautionary savings behaviour because oil price shock causes economic uncertainty that leads to a reduction of consumer confidence. Consequently, the real investment will decrease in the short and medium-term due to uncertainties about investment profitability. Also, the financial investment may also be affected depending on the degree of risk preference which dominates the financial market at the time of oil price shock. Further, oil price shocks cause a decline in the output in response to the consumer demand decrease. Thus, theoretically, all these effects negatively impact remittances.

On the other hand, oil price shocks likely to leave output constant in many cases by raising the final prices of goods. The impact of oil price shocks on inflation depends on the outcome from the contradicted deflationary pressures created by decreasing consumer demand and inflationary pressures created by the increasing prices of goods. In the same way, oil price shock's effects on unemployment subject to counterbalancing forces generated from both a decrease in production and inflation increase. Hence, the higher

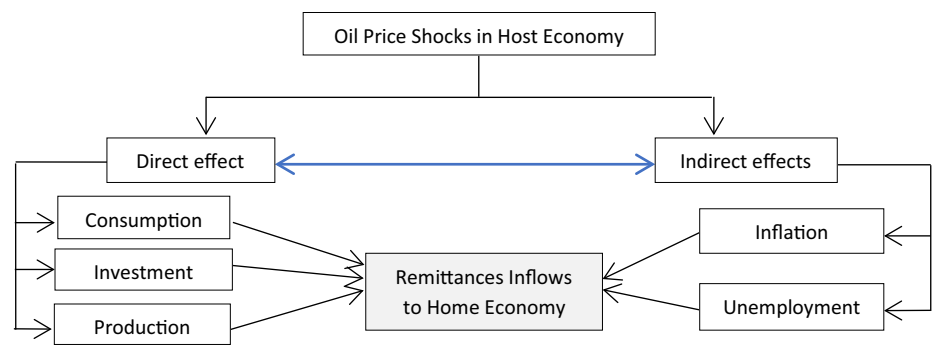

Source: The Author adapts it from literature

Response of remittances inflows 
inflation and unemployment rates, the fewer remittances outflow from host countries to home countries. Theoretically, economies should experience steeper recessions in response to positive oil price shocks and smaller expansions in response to adverse oil price shocks that in turn will affect remittances outflow negatively and positively, respectively.

\subsection{Empirical literature}

A large body of literature exists on the determinants of remittances from one side, and the relationship between oil price shocks and macroeconomic variables from the other side. However, there is less work that investigates the relationship between oil price shocks and remittances. Not only that but also there is a controversy in the literature on whether oil price has a positive or negative effect on remittances (Table I). All of that makes us claim that the impact of oil price shocks on remittances has not sufficiently investigated.

There is a strand of literature finds that remittances react positively to oil price shocks. From one side, few studies focused on inflowing remittances to recipient oil-importing countries (Makhlouf and Kasmaoui, 2017; Mohaddes and Raissi, 2013; Morshed and Pitafi, 2008; Lueth and Ruiz-Arranz, 2006). In the case of Morocco, Makhlouf and Kasmaoui (2017) show that there is a positive cointegration relationship between shocks in crude oil price and remittances inflows for the period 2004-2010 using ordinary least squares OLS and IV regressions, and VECM. Oil price rise leads to a decline in local purchasing power; as a consequence, migrants send more remittances to assist their families. However, there is no relationship in the short run. Also, Lueth and Ruiz-Arranz (2006) find that remittances in Sri Lanka are positively correlated with oil prices, offering a hedge against oil shocks.

Furthermore, Morshed and Pitafi's (2008) results suggest that the dynamic, positive oil price shocks have accompanied with an increase in inflowing remittances. That positive remittance effect partially mitigates the consequent reduction in output. Mohaddes and Raissi (2013) argue that oil price booms have an indirect positive effect on the GDP due to more significant foreign inflows such as remittances in Jordon. That indirect positive effect dominates the direct negative effect in the form of increases in the import bill due to higher oil prices.

On the other side, De et al. (2019) concluded that remittance flows to remittancedependent countries such as Egypt, Pakistan, Sri Lanka react positively to increases in oil prices and it modestly falls following oil price decreases. Also, they mentioned that the remittance outflows for migrant workers who work in the non-oil sector are elastic to oil price changes. In the short run, the elasticity is between 0.5 and 0.8 while in the long-term it

\begin{tabular}{|c|c|c|}
\hline Positive & Negative & No evidence \\
\hline $\begin{array}{l}\text { Authors } \\
\text { (Makhlouf and Kasmaoui, 2017) } \\
\text { remittances inflows to Morocco } \\
\text { (De et al., 2019) } \\
\text { remittances outflows from GCC } \\
\text { (Mohaddes and Raissi, 2013) } \\
\text { remittances inflows to Jordon } \\
\text { (Morshed and Pitafi, 2008) } \\
\text { remittances inflows to oil- } \\
\text { importing countries } \\
\text { (Lueth and Ruiz-Arranz, 2006) } \\
\text { remittances inflows to Sri Lanka }\end{array}$ & $\begin{array}{l}\text { (Khodeir, 2015) } \\
\text { remittances inflows to Egypt } \\
\text { (El-Sharabassy, 2008) } \\
\text { remittances inflows to Egypt } \\
\text { Statistically insignificant }\end{array}$ & $\begin{array}{l}\text { (Naufal and Termos, 2009) } \\
\text { remittances outflows from GCC } \\
\text { (Ratha and Mohapatra, 2009) } \\
\text { remittances outflows from GCC }\end{array}$ \\
\hline
\end{tabular}

Table I.

The relationship between oil price on remittances 
is between 0.6 and 1.1. Indeed, the non-oil sector GDP in the GCC is a crucial determinant of remittance outflows because Most migrant workers in the GCC employed in the non-oil sector. However, the oil sector GDP is a significant driver of non-oil sector GDP. In the same direction, in their analysis, other studies assume the positive association between oil price and remittances such as (Asatryan et al., 2017; Moawad Ahmed, 2016; Ahmed, 2013).

In contrast, two attempts have shown a negative relationship between oil price and remittances inflows in Egypt using mixed analysis techniques. El-Sharabassy (2008) finds that oil price has a negative and insignificant effect on remittances using the OLS method over 15 years sample. However, oil revenues in single GCC countries have a positive and significant impact on remittances inflows in Egypt. It means the oil export revenues in GCC countries strongly support economic growth, and consequently, affect remittances. While, by using annual data on Egypt from 1980 to 2012, the estimates from the VEC model show that remittances inflows negatively correlated with oil prices in the long and short run (Khodeir, 2015). It means that remittances inflows increased with the decreases of oil price, and that undermines their usefulness as a shock absorber.

There are another two critical empirical studies confirmed that the correlation between remittances outflows from oil-exporting countries and oil prices has no evidence. Ratha and Mohapatra (2009) argue that there is no correlation between falling oil prices and remittance outflows in the oil exporting countries in the Middle East. For instance, they reported that in Saudi Arabia remittance outflows uncorrelated with oil prices in recent years. Also, Naufal and Termos (2009) examined the elasticity of remittances from the GCC concerning the price of crude oil. They find that the response of remittances to changes in the price of oil is inelastic (less than 0.5).

Finally, as discussed above, there are conflicting results in the literature regarding the association between oil price shocks and remittances. From an empirical perspective, the previous studies used a wide range of econometric techniques such as ordinary least squares OLS and IV regressions, and VECM. However, this paper applied a VAR model to examine the reaction of remittances to different oil price shocks. Thus, this paper contributes to the recent research on remittances and oil price shocks.

\section{Overview of workers' remittances inflows in Egypt}

After the 1973 war, the Egyptian Government has approved the so-called "the open door" and trade liberalisation policy. This policy has released restrictions on migration; thus, allowed the largest boost to outward migrant flows to Libya and GCC countries. However, the Egyptian migrants became concentrated in Saudi Arabia due to the war in Libya in 2011. Approximately 86 per cent of Egyptian expatriates resides in Arab countries; most of them are in GCC countries with around 1.3 million in Saudi Arabia. In 2015, the total Egyptian population abroad was representing 7.4 million compared to 1.9 million in 2000, according to the Ministry of Foreign Affairs in Egypt. A steady increase in remittances has accompanied this boom in migrant outflows.

That makes Egypt one of the top remittance receivers in the world and the top recipient of remittances in the MENA region, according to the IMF and World Bank. Figure 2 shows the share of remittances in the GDP by country and remittances from GCC states as a share of total remittances. In 2016, Egypt received the lion's share of remittances in the MENA from GCC countries around $\$ 16.6 \mathrm{bn}$ which exceed 70 per cent of its total remittances inflows. That was representing 4.8 per cent of its GDP. Thus, the Egyptian economy is dependent on remittances inflow that mainly sent from GCC states which are highly dependent on oil rents. 


\section{REPS}

Figure 2.

Importance of remittance inflows in MENA 2016

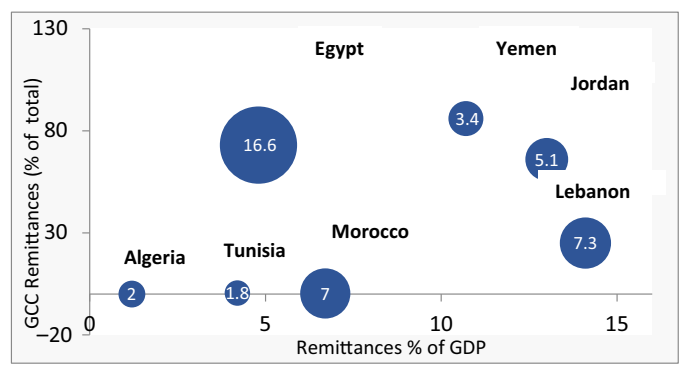

Source: Authors' calculations depending on World Bank, 2017 (Numbers in the circles refer to the total volume of remittances inflows in billions of US\$ in 2016)

During the past decade, remittances inflows in Egypt witnessed a boom and compensated for the sharp drop in foreign currency deposits. Egypt witnessed a decline in the Suez Canal, tourism and exports revenues as a result of the global economic slowdown after the global financial crisis of 2008. Total exports revenues decreased, and tourism revenues gradually declined by 67.7 per cent from their peak in 2011 (Figure 3). However, since 2009 inflowing remittances significantly increased and exceeded both foreign direct investment (FDI) and foreign aid inflows (Figure 4). Thus, inflowing remittances to Egypt exceed aid inflows and with a more stable pattern than FDI and foreign aid.

According to the Union of Arab Banks[3], the remittances sent to Egypt grew at a rate estimated at 9.7 per cent in 2014 and 0.7 per cent in 2015. It means that remittances sent to Egypt witnessed a decline in 2015 and this coincided with a decline in oil prices since mid2014. Therefore, this brings up to the question of whether the decline of oil prices negatively impacts the remittances inflow to Egypt. So, it was necessary to link remittances inflows to Egypt with oil prices in GCC countries and investigate the dynamic relationship between them. Figure 5 shows that changes in oil price and changes in remittances inflow are moving together with lag moves. Hence, it seems that there a positive correlation between changes in oil price and changes in remittances.

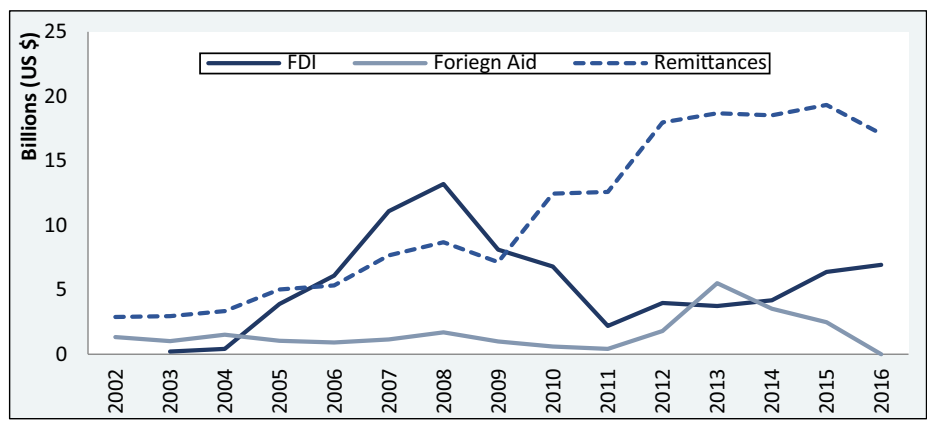

Figure 3.

Remittances are a primary source of foreign currency

Source: Authors' calculations depending on the Central Bank of Egypt data 


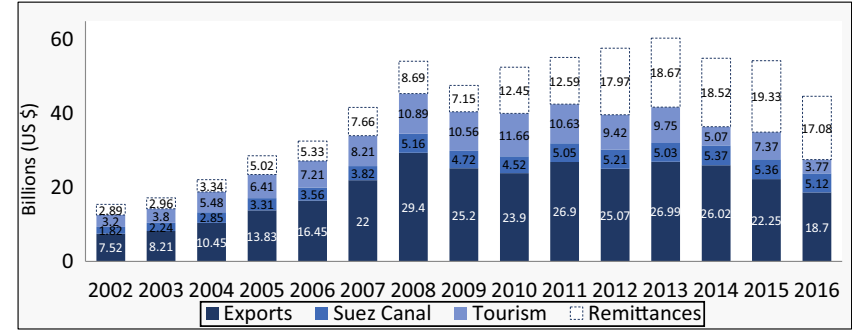

Source: Authors' calculation based on Central Bank of Egypt, Annual Report Different Volumes (Fiscal year starts at the end of June each year and ends in the same date in the next year. 2016 means FY 2015/2016)

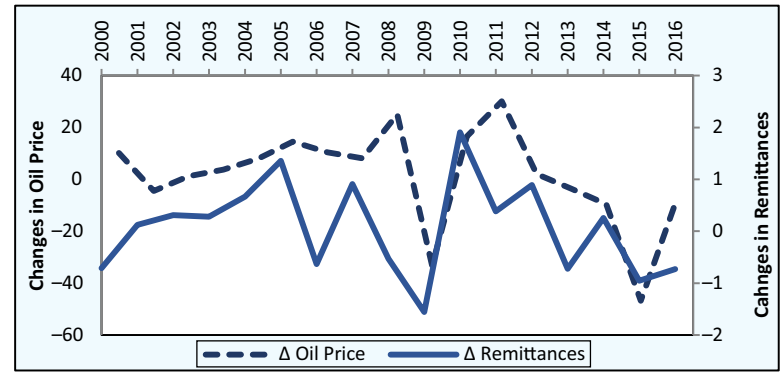

Source: Authors' calculations depending on the World Bank (WDI) data and OPEC data
Response of remittances inflows

Figure 4.

Sources of foreign currency

Figure 5.

Oil price and egypt remittances inflows

Table II shows specific oil supply disruptions that lead to changes in oil prices at the year of disruption and changes in remittances inflows to Egypt next year after a specific disruption. We find that the considerable VAR's basic form; however, in the long run, these disruptions cause both negative and positive OPEC crude oil price shocks. The interesting is that changes in oil prices are associated and moving together with changes in remittances inflow to Egypt in the year after the shock. It means a positive change in oil price followed by an increase in remittances inflow to Egypt. while remittances declined in response to negative changes in oil price due to other disruptions. Thus, even under the same kind of shocks such as supply-side shocks, there are different effects on oil prices changes. That in turn show to what extent oil price shocks might have asymmetric effects on remittance inflows to Egypt.

\section{Data and methodology}

\subsection{Data}

The data set used in this study includes the latest annual observations available for all variables that cover the period from 1960 to 2016 in Egypt. The data mainly obtained from four sources: the central bank of Egypt (CBE), the World Development Indicators (WDI) of the World Bank, the International Financial Statistics (IFS) of the International Monetary Fund (IMF) and OPEC databases. Table I illustrates the descriptive statistics of our variables all in logs transformations. The data series and notation used in this study are as follows: remittances inflows to Egypt (remit), oil price (oilp), the exchange rate (exch), money 


\section{REPS}

Table II.

Time $(t)$

Event

Changes in remittances

October 1956

June 1967

October 1973

October 1973

October 1978

September 1980

August 1990

July 1997

September 2001

December 2002

March 2003

2008

December 2010

December 2014

The Tripartite Aggression

Arab-Israeli War

6th October War

OPEC Oil embargo

Iranian revolution

Iran-Iraq War

Iraq-Kuwait war

South East Asian financial crisis

Terrorists attack

Political unrest in Venezuela

Invasion of Iraq

financial crisis

The Arab Spring revolutions

OPEC overproduction

$\begin{array}{cc}\text { Change in oil } & \text { Changes in remittances } \\ \text { crude price } \%(t) & \text { inflow to Egypt } \%(t+1)\end{array}$

Source: Authors' calculations

supply (bm), the ratio of home GDP to host GDP (hostgdp) and domestic credit (dc). Table III summarises the descriptive statistics.

Unit roots tests are important to know if shocks have permanent or transitory effects. We tested the stationarity of the variables by applying augmented Dickey-Fuller (ADF) and Philipps Perron (PP) tests. The Unit root analysis revealed that oilp, hostgdp, exchr, $d c$ and $b m$ had a unit root at level but was found to be stationary at first difference of order 1(1) in both models with trend and without a trend, and all series integrated of order one, as in Table IV. Therefore, we expect the oil price shocks to have permanent effects on remittances.

As Table V shows after applying the Johansen cointegration test, there is at least three cointegration since Trace statistic is less than Critical value. It means that there are at least three long-run relationships between the variables. That makes analysing the IRF more interesting because we expected to see long-run responses and the effects of oil price shocks will not die out at least in the short and medium run. Furthermore, one of the critical decisions when applying the VAR model is to determine the number of lags that should be included in the model. According to HQIC which indicated the median, the optimal lags for the model is two lags.

\subsection{Empirical methodology}

Our vector autoregressive system is estimated in levels of six endogenous macroeconomic variables: oilp, hostgdp, exchr, dc, remit and bm, all in natural logarithms (logs). Using VAR's basic form[4]: $y_{t}=\left(y_{1 t}, \ldots, y_{3 t}, \ldots . y_{6 t}\right)$, the VAR (p)-process defined as:

Table III.

Descriptive statistics of the variables (all in $\operatorname{logs})$

\begin{tabular}{lcccccc}
\hline Statistics & oilp & hostgdp & exchr & dc & remit & bm \\
\hline Mean & 2.627 & -2.454 & 0.325 & 4.354 & 1.443 & 4.216 \\
Median & 2.914 & -2.256 & -0.356 & 4.390 & 1.730 & 4.362 \\
Maximum & 4.695 & -1.943 & 2.04 & 4.708 & 2.679 & 4.578 \\
Minimum & 0.190 & -3.501 & -1.054 & 3.837 & -3.013 & 3.510 \\
SD & 1.408 & 0.501 & 1.145 & 0.258 & 1.204 & 0.354 \\
Observations & 57 & 48 & 56 & 51 & 50 & 51 \\
\hline
\end{tabular}




\begin{tabular}{|c|c|c|c|c|c|c|c|c|}
\hline \multirow[b]{3}{*}{ Variables } & \multicolumn{4}{|c|}{$\mathrm{ADF}$} & \multicolumn{4}{|c|}{ PP } \\
\hline & \multicolumn{2}{|c|}{ Without trend } & \multicolumn{2}{|c|}{ With trend } & \multicolumn{2}{|c|}{ Without trend } & \multicolumn{2}{|c|}{ With trend } \\
\hline & Level & First diff & Level & Firct & evel & First diff & Level & First diff \\
\hline $\begin{array}{l}\text { oilp }_{t} \\
\text { hostgdp }_{t} \\
\text { exchr }_{t} \\
\text { dc }_{t} \\
\text { remit }_{t} \\
\text { bm }_{t}\end{array}$ & $\begin{array}{l}-1.360 \\
-1.096 \\
-0.521 \\
-2.259 \\
-2.619^{*} \\
-2.088\end{array}$ & $\begin{array}{l}-3.55^{* * *} \\
-3.45^{* *} \\
-4.72^{* * *} \\
-2.289 \\
-7.80^{* * *} \\
-4.34^{* * *}\end{array}$ & $\begin{array}{l}-1.392 \\
-0.827 \\
-2.565 \\
-2.618 \\
-2.046 \\
-1.405\end{array}$ & $\begin{array}{l}-6.61^{* * *} \\
-3.42^{*} \\
-4.69^{* * *} \\
-6.03^{* * * *} \\
-9.26^{* * *} \\
-4.65^{* * *}\end{array}$ & $\begin{array}{l}-1.394 \\
-0.945 \\
-0.224 \\
-2.011 \\
-2.635^{*} \\
-1.729\end{array}$ & $\begin{array}{l}-6.61 \text { *** } \\
-3.50^{* *} \\
-4.62^{* * *} \\
-6.12^{* * *} \\
-7.61^{* * *} \\
-4.41^{* * *}\end{array}$ & $\begin{array}{l}-1.669 \\
-1.621 \\
-2.123 \\
-1.892 \\
-2.003 \\
-1.053\end{array}$ & $\begin{array}{l}-6.62^{* * * *} \\
-3.16^{*} \\
-4.58^{* * * *} \\
-6.12^{\text {**** }} \\
-8.62^{\text {**** }} \\
-4.65^{\text {**** }}\end{array}$ \\
\hline
\end{tabular}

Response of remittances inflows

Notes: Using MacKinnon $p$-values (HO: unit root exists, we denote with *, **, *** the rejection of the null hypothesis at a $10 \% / 5 \% / 1 \%$ significance level)

Table IV.

Unit root analysis

\begin{tabular}{lcccccc}
\hline Rank & Eigenvalue & Trace statistic & Critical value & Probability & MaxEigen statistic & Probability \\
\hline $\mathrm{r}=0$ & 0.710 & 154.898 & 95.753 & 0.000 & 57.001 & 0.000 \\
$\mathrm{r} \leq 1$ & 0.639 & 97.897 & 69.818 & 0.001 & 46.976 & 0.000 \\
$\mathrm{r} \leq 2$ & 0.489 & 50.920 & 47.856 & 0.025 & 30.922 & 0.017 \\
$\mathrm{r} \leq 3$ & 0.179 & $19.997^{*}$ & 29.797 & 0.423 & 9.087 & 0.825 \\
$\mathrm{r} \leq 4$ & 0.168 & 10.910 & 15.494 & 0.217 & 8.494 & 0.330 \\
$\mathrm{r} \leq 5$ & 0.051 & 2.416 & 3.841 & 0.120 & 2.416 & 0.120
\end{tabular}

Note: *Indicates that there are at least three co-integrating equations at a $5 \%$ significance level

Table V. Johansen cointegration test results

$$
y_{t}=A_{1} y_{t-1}+\ldots+A_{p} y_{t-p}+u_{t}
$$

where $A_{i}$ is $(6 * 6)$ coefficient matrices for $i=1, \ldots, p$ and the order $p$ represents the number of lags. Thus, we have six variables and six equations, an equation for each variable; each equation includes $p$ lags of each variable and one error term. An unrestricted VAR includes all variables in each equation. As so the form of unrestricted VAR system in this study can also be written as a VAR (1)-process:

$$
\left[\begin{array}{c}
\text { oilp } \\
\text { hostgdp } \\
\text { exchr } \\
d c \\
\text { remit } \\
\text { bm }
\end{array}\right]=\left[\begin{array}{l}
c_{1} \\
c_{2} \\
c_{3} \\
c_{4} \\
c_{5} \\
c_{6}
\end{array}\right]+A(l)\left[\begin{array}{c}
\text { oilp }_{t-1} \\
\text { hostgdp pt-1 }_{t} \\
\text { exchr }_{t-1} \\
d c_{t-1} \\
\text { remit }_{t-1} \\
\text { bm }_{t 1}{ }^{t-1}
\end{array}\right]+\left[\begin{array}{c}
\varepsilon_{1 t} \\
\varepsilon_{2 t} \\
\varepsilon_{3 t} \\
\varepsilon_{4 t} \\
\varepsilon_{5 t} \\
\varepsilon_{6 t}
\end{array}\right]
$$

The model specification is mainly based on Singh et al. (2009) with adjustments. In addition to remittances (remit) and oil price (oilp), we included domestic credit (dc) as indicators for financial depth. Financial development induces the worker's remittances to the home country in the long-run (Agir et al., 2011). Moreover, financial development has a complementary relationship with remittances to ensure economic growth (El Hamma, 2016). To take into account the monetary policy we have used the money supply as an instrument 
of managing monetary policy. The monetary policy in home remittance receiving countries will go up to a point affects remittances inflows through inflation and interest rate. However, the effect of interest rate differential between home and host countries on remittances still debated in the literature.

Again, as income in both home and host countries affect remittances, we include the ratio of GDP in Egypt to GDP in the top host country (hostgdp) in our model. Remittances are strongly pro-cyclical vis-à-vis sending country income (Abdih et al., 2012). Further, we added real exchange rate (exchr) as real exchange depreciation affects remittances positively and can explain through two main channels. First, a real depreciation will have a positive income effect so that remittances will be positive. Second, real exchange depreciation will lead to more considerable demand for the home country good through standard substitution effects (Faini, 1994). Finally, it was necessary to include a dummy variable (d) to control other significant shocks that might cause bias results. Identifying the dummy variable depends on historical events based on previous studies.

For robustness check, we tried to include (Polity) variable, as an indicator of political risk and institutions, in our model specification instead of money supply (bm). However, the responses of remittances to asymmetric oil price shocks have not changed. That is because the economic factors are regularly the central emigration causes in case of Egypt (Ghoneim, 2010) and the decision to remit links to the causes of migration (Hagen-Zanker and Siegel, 2007). So, we decided to focus on other economic variables.

A critical challenging decision to apply the VAR model is the ordering of the variables. Indeed, the Cholesky decomposition is not unique; it imposes over restrictive recursive ordering. It means that the results for IRFs and VDCs will depend on the ordering of the variables. A possible solution for ordering problem is to try different orderings and compare the IRFs and VDCs for each order. However, one alternative solution is the generalised VAR which is invariant to the ordering of the variables in the VAR. Therefore, it results in one unique solution (Pesaran and Shin, 1998).

Non-policy macroeconomic variables, such as oil price and GDP, should be ordered first before any policy variables, such as a money supply (Sonmez, 2016). Moreover, non-policy variables affect other variables contemporaneously through their lagged values. Also, policy shocks do not affect the macroeconomic variables contemporaneously, but only with a lag (Bernanke and Blinder, 1992). So, based on that rule and from similar previous studies experiences, we chose to order the variables as follows: oil price (oilp), GDP ratio (hostgdp), an exchange rate (exchr), domestic credit $(d c)$, remittances (remit), money supply $(\mathrm{bm})$. For that order, we did not find significant changes by comparing Cholesky decomposition with generalised decomposition. Therefore, we decided to rely on this order.

Precisely, we defined two oil price shocks specifications. They are specified- logdifference of nominal oil price (Hamilton, 1983) and oil price increase distinguished from oil price decrease (Mork, 1989). Thus, annually changes of nominal oil prices, defined as the first log difference transformation of nominal oil price is specified as:

$$
\text { dloilp }_{t}=\text { dlnoilp }_{\mathrm{t}}-\text { dlnoilp }_{\mathrm{t}-1}
$$

where oilpt is oil price in period $t, d$ is the first difference, plus $l$ is the log transformation. Also, we distinguished oil price increases from oil price decreases, as the rationale for this specification lies on the observed asymmetry in the way macroeconomic variables react to oil price changes. The oil price increase is specified as dloilpp $=\max (0$, dloilp), while 
negative oil price changes are specified as dloilpn $=\max$ (0, dloilp). Finally, we added two lags in the model according to the diagnostic tests.

\section{Empirical results and policy implications}

\subsection{Impulse response functions}

Impulse response functions measure the dynamic qualitative response of remittances inflows in the system to exogenous shocks in oil prices. Figure 6 shows the IRFs of remittances after log-difference of oil price and oil price increase distinguished from oil price decrease shocks using annual data from 1960 to 2016. The undotted line represents the response of the current and future values of remittances (remit), and the dotted lines refer to \pm 1 standard deviation in oil prices. These dotted lines plot the confidence intervals which have been computed via asymptotic standard errors. The magnitude of the responses is on the vertical axis and the periods (years) after the shock are on the horizontal axis.

The IRFs show that real and nominal oil price shocks almost lead to the same positive response in remittances. The reaction of remittances is significantly above its initial level
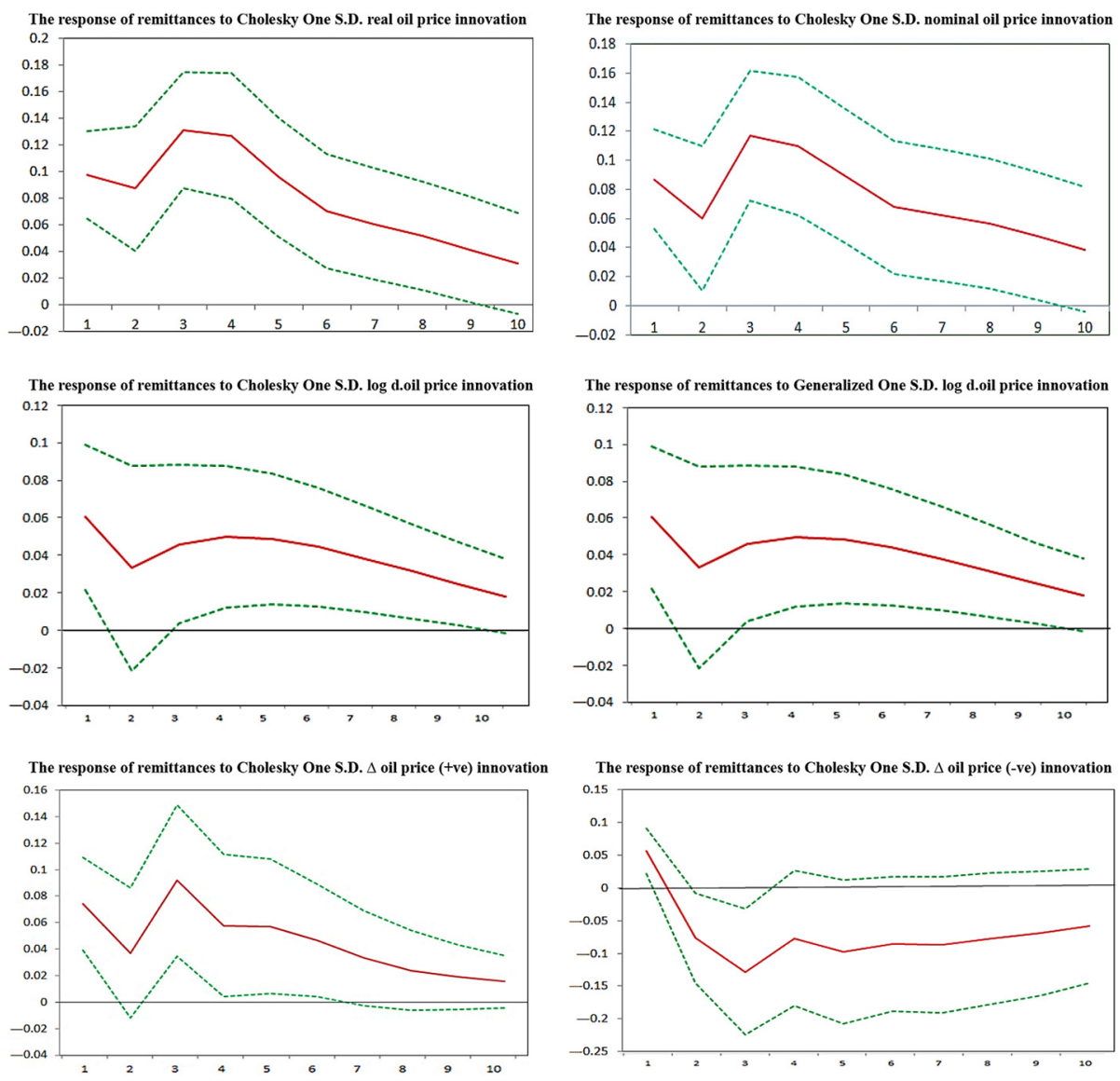
. 


\section{REPS}

during the first nine years to innovation to oil prices. However, in the long run, this effect does not remain significant. Also, the response of remittances (remit) to one standard shock to $\log$ difference oil price is positive. It is significantly different from zero during the whole period except for the second and tenth year. The result does not differ from Cholesky decomposition to generalised decompositions. Thus, oil price shocks in log differences are affecting remittances positively. That is on a significant scale in the short run then diminishing in the long term.

The IRFs also suggest that the response of remittances inflows (remit) to one standard positive shock to oil price is positive. It is significantly above its initial level in the first year and over the period from the third to the sixth year. While remittances responded significantly in the first three years to negative oil price innovation, it responds positively in the first year and negatively in second and third years. Thus, these results reveal that the responses of remittances to positive and negative oil price shocks are significant in the short-run and insignificant in the long run. Also, inflowing remittances increases in response to positive oil price shocks and decreases in response to negative oil price shocks. Finally, the magnitude of these responses reaches its peak or trough in the third year.

\subsection{Variance decomposition analysis}

The forecast error variance decomposition (FEVD) is useful in assessing how shocks to economic variables reverberate through a system. Tables VI and VII demonstrate the variance decomposition of remittances (remit) in different VAR models that use either nominal oil price or real oil price. They show that 13.51 and 32.20 per cent of the variation in remittances are explained by nominal oil price after one and five years,

\section{Table VI.}

Variance

decomposition analysis (VDA) using nominal oil price

\begin{tabular}{lcccc}
\hline & \multicolumn{2}{c}{$\begin{array}{c}\text { Variance decomposition of remittances } \\
\text { Years ahead }\end{array}$} & $\begin{array}{c}\text { Variance decomposition of oil price } \\
\text { \% due to nominal oil price }\end{array}$ & $\begin{array}{c}\text { V due to remittances } \\
\text { \% due to oil price }\end{array}$ \\
\hline 1 & 13.51 & 73.22 & 100 & 0.00 \\
2 & 15.02 & 57.55 & 96.77 & 0.06 \\
3 & 22.77 & 48.46 & 95.66 & 0.12 \\
4 & 29.29 & 42.50 & 94.75 & 0.37 \\
5 & 32.20 & 39.49 & 93.78 & 0.83 \\
10 & 34.18 & 32.22 & 91.82 & 1.31 \\
15 & 32.73 & 29.86 & 89.76 & 1.24 \\
20 & 31.53 & 28.66 & 89.28 & 1.25 \\
\hline
\end{tabular}

\section{Table VII.}

Variance decomposition of remittances using real oil price

\begin{tabular}{rrrrrrr}
\hline \multicolumn{7}{c}{ Variance decompositions of remit } \\
Year & roilp & Hostgdp & exchr & dc & remit & bm \\
\hline 1 & 11.75 & 5.79 & 7.56 & 10.68 & 61.01 & 3.19 \\
2 & 11.56 & 11.84 & 15.35 & 8.15 & 50.21 & 2.85 \\
3 & 18.18 & 14.21 & 14.23 & 8.41 & 42.63 & 2.30 \\
4 & 24.85 & 14.93 & 12.43 & 7.35 & 38.31 & 2.10 \\
5 & 28.22 & 16.11 & 11.69 & 6.69 & 35.36 & 1.91 \\
10 & 32.07 & 21.42 & 12.13 & 5.46 & 27.07 & 1.81 \\
15 & 31.13 & 23.81 & 12.77 & 5.13 & 24.88 & 2.25 \\
20 & 30.23 & 25.18 & 12.64 & 5.54 & 24.09 & 2.29 \\
\hline
\end{tabular}


respectively. In the same manner, 11.75 and 28.22 per cent of the change in remittances are explained by real oil price after one and five years, respectively. Therefore, these results indicate that the effects of nominal oil price shocks and real oil price shocks are very close to a substantial extent. Thereby, using nominal or real oil price does not cause a significant dispute.

As shown in Tables VIII and IX, they illustrate the variance decompositions of remittances (remit) in response to innovations in oil price increases and decreases. Indeed, the volatility in both oil price increases and decreases affect remittances inflow in the model to varying degrees. For instance, positive oil price shocks initially account for about 10.26 per cent of the variation in remittances (remit), increasing to a share of 13.76 per cent in three years after the shock. The negative oil price shocks account for about 5.79 per cent of the variation in remittances after a year. That is compared to18.46 per cent in the three years after the shock. Consequently, these results reveal that oil price decreases are more influential than oil price increases.

\subsection{Policy implications}

Our prime concern is with the need to determine the behaviour of inflowing remittances in Egypt. The objective of this paper is to consider how remittances inflows react to asymmetric oil price shocks because it is an essential point for the oil importing countries in general and Egypt in particular. We draw on our key findings to show that positive oil price shocks have a significant positive impact on remittances inflows to Egypt to develop the debate in the literature. Also, the results reveal that oil price increases are more important than oil price decreases.

\begin{tabular}{|c|c|c|c|c|c|c|c|}
\hline Year & $\Delta$ oil price $^{+v e}$ & $\begin{array}{l}\text { Variance d } \\
\text { Hostgdp }\end{array}$ & $\begin{array}{l}\text { sitions o } \\
\text { exchr }\end{array}$ & dc & remit & $\mathrm{bm}$ & \\
\hline 1 & 10.26 & 0.84 & 4.31 & 5.17 & 79.42 & 0.00 & \\
\hline 2 & 9.90 & 4.89 & 16.60 & 4.26 & 64.24 & 0.09 & \\
\hline 3 & 13.76 & 6.59 & 19.24 & 8.10 & 54.21 & 0.08 & \\
\hline 4 & 15.35 & 7.22 & 19.85 & 8.51 & 48.77 & 0.29 & able Vill. \\
\hline 5 & 16.46 & 7.07 & 19.59 & 8.69 & 47.89 & 0.28 & Variance \\
\hline 10 & 17.76 & 6.89 & 16.41 & 9.48 & 47.10 & 0.35 & decomposition \\
\hline 15 & 17.49 & 7.87 & 18.74 & 9.53 & 45.94 & 0.43 & analysis (VDA) using \\
\hline 20 & 16.82 & 8.71 & 19.33 & 10.27 & 44.42 & 0.45 & $\Delta$ oil price ${ }^{+v e}$ \\
\hline
\end{tabular}

\begin{tabular}{|c|c|c|c|c|c|c|c|}
\hline Year & $\Delta$ oil price $e^{-v e}$ & $\begin{array}{l}\text { Variance } \\
\text { Hostgdp }\end{array}$ & $\begin{array}{r}\text { ositions } \\
\text { exchr }\end{array}$ & $\mathrm{dc}$ & Remit & $\mathrm{bm}$ & \\
\hline 1 & 5.79 & 3.40 & 10.98 & 5.61 & 74.20 & 0.00 & \\
\hline 2 & 10.47 & 10.26 & 21.27 & 4.87 & 52.83 & 0.29 & \\
\hline 3 & 18.46 & 10.23 & 20.69 & 10.25 & 40.15 & 0.21 & \\
\hline 4 & 19.34 & 10.28 & 20.68 & 11.98 & 37.43 & 0.29 & I able IX. \\
\hline 5 & 21.79 & 9.09 & 19.43 & 13.36 & 35.64 & 0.68 & Variance \\
\hline 10 & 27.81 & 7.06 & 16.52 & 13.09 & 32.51 & 3.01 & decomposition \\
\hline 15 & 27.49 & 9.10 & 15.92 & 13.68 & 30.64 & 3.16 & analysis (VDA) using \\
\hline 20 & 26.71 & 9.99 & 15.47 & 14.82 & 29.87 & 3.14 & $\Delta$ oil price ${ }^{-v e}$ \\
\hline
\end{tabular}


Although Egypt has a stock of heavy crude oil, it unsuitable for oil refining plants in Egypt. So, Egypt exports the heavy crude oil and imports light crude oil mainly from Saudi and UAE, at the same time. However, total oil products imports are higher than total oil products exports. Egypt has a deficit in solar, gasoline with a high portion of octane, gas piping, sulfur and coke. That led to a growing deficit in the Egyptian oil merchandise balance during the last decade. For instance, in fiscal year 2015/2016 total oil exports were US\$5.7bn, while total oil imports were US\$9.3bn, causes US\$3.5bn deficit in oil balance[5]. That means that oil price increases would make an additional cost that cannot be avoided. Also, Egypt still subsidies petroleum products with net subsidies cost as well. That would put more pressure on the public deficit beside its effect on the balance of payments which needs foreign currency, namely US\$, to finance its deficit and the important increasing bill. So, the evidence of this paper suggests that Egypt can benefit from the positive effect of remittances. That is by considering remittances inflows as an alternative that offsets the loss of foreign currency and may mitigate oil costs in the public budget due to oil price increases.

Policymakers in Egypt are well advised to encourage inflowing remittances by the following policy recommendations:

- increasing the numbers of migrants to oil exporting countries;

- promoting the financial sector; and

- reducing the transaction costs.

Oil price changes have two contradictory impacts on the oil importing economies. In Egypt, sharp oil price increases positively raise the oil exporting bills. At the same time, it increases remittances inflows. The net impact mainly depends on the relative size of oil imports and remittances inflows. Thus, although the positive association between oil price increases and remittances inflows to Egypt, it may be the case that the net impact of oil price increases on the Egyptian economy is negative at least in the short term. So, further research will be needed to determine the net impact of oil prices shocks on the Egyptian economy to come up with a good understanding of the whole picture. Also, we suggest the researchers use bilateral data because bilateral data have not yet been studied to estimate determinants of workers' remittances on Egypt from Arab Gulf countries. Also, use microeconomic level variables to improve our understanding of the different impacts of oil shocks on remittances.

\section{Conclusions}

The connection between remittances and oil prices is relevant to Egypt because it is quite vulnerable to oil price shocks. Global oil price raise directly increases the oil-import bill in the Egyptian balance of payment. Remittances are one of the most significant sources of foreign currencies which build the international reserves in Egypt and used for meeting external bills. The majority of these remittances mostly coming from GCC countries. So, one of the substantial factors that affect GCC economies and through which remittances can be affected is oil price.

This paper analyses the dynamic response of remittances inflows in Egypt to asymmetric oil price shocks over the periods from 1960 to 2016. Using a multivariate VAR model, we examined the impulse response function (IRF) and forecast error variance decompositions (FEVD). Our findings indicate that using nominal or real oil price does not cause a significant dispute. It reveals that the responses of remittances inflow to asymmetric oil price shocks are significantly asymmetric too. Inflowing remittances increase in response 
to positive oil price shocks, and it declines in response to negative oil price shocks. The magnitude of these responses reaches its peak or trough in the third year. Also, these responses are significant in the short and medium-run and insignificant in the long run. Finally, the results show that oil price decreases are more influential than oil price increases. So, these findings suggest that remittances inflows in Egypt are pro-cyclical with the oil price.

In conclusion, this paper develops a debate in the literature. It contributes to the little existing studies on the relationship between oil price and remittances. The novelty of this paper is through applying a VAR model using new dataset spanning 1960-2016 on Egypt. This paper has clear policy implications for determining the behaviour of remittances and highlighting the impact of different kinds of oil prices shocks on remittances. That will help policymakers to efficiently benefit from the positive effect of remittances which can offset the loss of foreign currency due to sharp oil price increases.

\section{Notes}

1. The six GCC countries are Bahrain, Kuwait, Oman, Qatar, Saudi Arabia (KSA) and United Arab Emirates (UAE) States.

2. The investment saving-liquidity preference money supply.

3. The Union of Arab Banks www.uabonline.org/en/research

4. For more detailed information, refer Pfaff (2008).

5. Central Bank of Egypt data, Monthly Statistical Bulletin, Volume No. (242) May 2017.

\section{References}

Abdih, M.Y., Chami, M.R., Ebeke, M.C. and Barajas, M.A. (2012), "Remittances channel and fiscal impact in the Middle East, North Africa, and Central Asia”, working paper, 12/104, International Monetary Fund, available at: www.imf.org/external/pubs/ft/wp/2012/ wp12104.pdf

Adebiyi, M., Adenuga, A., Abeng, M. and Omanukwue, P. (2009), "Oil price shocks, exchange rate and stock market behaviour: empirical evidence from Nigeria", Proceedings of the 14th Annual Conference of the African Econometric Society, available at: http://citeseerx.ist.psu.edu/viewdoc/ download?doi=10.1.1.589.4418\&rep=rep1\&type $=$ pdf

Agir, H., Kar, M. and Nazlioglu, S. (2011), "Do remittances matter for financial development in the MENA region? Panel cointegration and causality analysis", Empirical Economics Letters, Vol. 10 No. 5, pp. 449-456, available at: www.eel.my100megs.com/volume-10number-5.htm

Ahmed, F.Z. (2013), "Remittances deteriorate governance", Review of Economics and Statistics, Vol. 95 No. 4, pp. 1166-1185, available at: https://doi.org/10.1162/REST_a_00336

Asatryan, Z., Bittschi, B. and Doerrenberg, P. (2017), "Remittances and public finances: evidence from oil-price shocks", Journal of Public Economics, Vol. 155, pp. 122-137, available at: https://doi.org/ 10.1016/j.jpubeco.2017.09.009

Beck, T. and Peria, M.S.M. (2011), "What explains the price of remittances? An examination across 119 country corridors", The World Bank Economic Review, Vol. 25 No. 1, pp. 105-131, available at: http://documents.worldbank.org/curated/en/204211468148503043/What-explains-the-priceof-remittances-an-examination-across-119-country-corridor

Bernanke, B.S. and Blinder, A.S. (1992), "The federal funds rate and the channels of monetary transmission", The American Economic Review, pp. 901-921. 
Canas, J. Coronado, R. and Orrenius, P.M. (2007), "Explaining the increase in remittances to Mexico", Federal Reserve Bank of Dallas, Southwest Economy, Issue 4, July/August, available at: www. dallasfed.org/ /media/documents/research/swe/2007/swe0704b.pdf

De, S., Quayyum, S., Schuettler, K. and Yousefi, S.R. (2019), “Oil prices, growth, and remittance outflows from the Gulf cooperation council", Economic Notes, pp. 1-16, available at: https://doi.org/ 10.1111/ecno.12144

El-Sharabassy, A. (2008), "Oil and remittances in the Middle East", Doctor of Philosophy (PhD), dissertation, International Studies, Old Dominion University, available at: https://doi.org/ 10.25777/c883-dd43

Faini, R. (1994), "Workers remittances and the real exchange rate", Journal of Population Economics, Vol. 7 No. 2, pp. 235-245, available at: https://doi.org/10.1007/BF00173621

Farzanegan, M.R. and Hassan, S.M. (2016), "How does the flow of remittances affect the trade balance of the Middle East and North Africa?”, working paper, CESifo, Series No. 6172, 8 November, available at SSRN: https://ssrn.com/abstract $=2885249$

Farzanegan, M.R. and Markwerdt, G. (2009), "The effects of oil price shocks on the Iranian economy", Energy Economics, Vol. 31 No. 1, pp. 134-151, available at: https://doi.org/10.1016/j. eneco.2008.09.003

Finn, M.G. (2000), "Perfect competition and the effects of energy price increases on economic activity", Journal of Money, Credit and Banking, Vol. 32 No. 3, pp. 400-416, available at: https://doi.org/ $10.2307 / 2601172$

Ghoneim, A.F. (2010), "Labour migration for decent work, economic growth and development in Egypt”, Working paper, International Labour Organization, No. 106, 15 April.

Goldberg, M.A. and Levi, M.D. (2008), “The impact of remittances on economic growth”, MasterCard Worldwide Insights, pp. 1-21, available at: www.slideshare.net/ifad/the-impact-of-remittances

Gupta, P. (2006), "Macroeconomic determinants of remittances: evidence from India", Economic and Political Weekly, Vol. 41 No. 26, pp. 2769-2775, 30 June, available at: www.jstor.org/stable/4418406

Hagen-Zanker, J. and Siegel, M. (2007), “The determinants of remittances: a review of the literature", Working paper, MGSoG, No. 3, available at: http://dx.doi.org/10.2139/ssrn.1095719

Hamilton, J.D. (1983), "Oil and the macroeconomy since world war II", Journal of Political Economy, Vol. 91 No. 2, pp. 228-248, available at: www.jstor.org/stable/1832055.

Hamilton, J.D. (1996), "This is what happened to the oil price-macroeconomy relationship”, Journal of Monetary Economics, Vol. 38 No. 2, pp. 215-220, available at: https://doi.org/10.1016/S03043932(96)01282-2.

Hamilton, J.D. (2003), “What is an oil shock?”, Journal of Econometrics, Vol. 113 No. 2, pp. 363-398, available at: https://doi.org/10.1016/S0304-4076(02)00207-5

IMF (2009), "International transactions in remittances", International Monetary Fund, Washington, DC, available at: www.imf.org/external/np/sta/bop/2008/rcg/pdf/guide.pdf

Khodeir, A.N. (2015), "Migration remittances inflows and macroeconomic shocks: the case of Egypt", International Journal of Economics and Financial Issues, Vol. 5 No. 4, pp. 1001-1010, available at: www.econjournals.com

Kilian, L. (2009a), "Not all oil price shocks are alike: disentangling demand and supply shocks in the crude oil market", American Economic Review, Vol. 99 No. 3, pp. 1053-1069, June, available at: https://doi.org/10.1257/aer.99.3.1053

Kilian, L. (2009b), "Oil price shocks, monetary policy and stagflation", Discussion paper, CEPR, No. DP7324, June, available at: https://ssrn.com/abstract $=1433920$

Lueth, E. and Ruiz-Arranz, M. (2006), “A gravity model of workers' remittances”, working paper 06/ 290, International Monetary Fund, available at: www.imf.org/external/pubs/ft/wp/2006/ wp06290.pdf 
McCoy, A., Nziramasanga, M. and Yoder, J. (2007), "An empirical examination of the factors affecting remittance by Mexican migrants in the United States",The American Agricultural Economics Association Annual Meeting, Portland, OR, Vol. 29.

Makhlouf, F. and Kasmaoui, K. (2017), "The impact of oil price on remittances: the case of Morocco", Journal of Energy and Development, Vol. 43, pp. 293-310, available at: www.jstor.org/stable/ 26539577

Moawad Ahmed, S. (2016), "The impact of oil prices on the economic growth and development in the MENA countries", MPRA Paper No. 89073, available at: https://mpra.ub.uni-muenchen.de/ 89073/

Mohaddes, K. and Raissi, M. (2013), "Oil prices, external income, and growth: lessons from Jordan", Review of Middle East Economics and Finance, Vol. 9 No. 2, pp. 99-131, available at: https://doi. org/10.1515/rmeef-2012-0011

Mork, K.A. (1989), "Oil and the macroeconomy when prices go up and down: an extension of Hamilton's results”, Journal of Political Economy, Vol. 97 No. 3, pp. 740-744, available at: www. jstor.org/stable/1830464

Morshed, A.K.M. and Pitafi, B.A. (2008), "Oil prices and remittances: impacts of oil price shocks on the macroeconomy of a small, oil importing, and labour exporting country”, Discussion paper 59, Southern Illinois University Carbondale, available at: http://opensiuc.lib.siu.edu/econ_dp

Naufal, G. and Termos, A. (2009), "The responsiveness of remittances to the oil price: the case of the GCC”, Discussion paper, IZA, No. 4277, available at: http:/nbnresolving.de/urn:nbn:de:101:12009082062

Niimi, Y., Pham, T.H. and Reilly, B. (2009), "Determinants of remittances: recent evidence using data on internal migrants in Vietnam", Asian Economic Journal, Vol. 23 No. 1, pp. 19-39, available at: https://doi.org/10.1111/j.1467-8381.2009.02000.x

Pesaran, H.H. and Shin, Y. (1998), "Generalized impulse response analysis in linear multivariate models”, Economics letters, Vol. 58 No. 1, pp. 17-29, available at: https://doi.org/10.1016/S01651765(97)00214-0

Pfaff, B. (2008), "VAR, SVAR and SVEC models: implementation within R package vars", Journal of Statistical Software, Vol. 27 No. 4, pp. 1-32, available at: http://vps.fmvz.usp.br/CRAN/web/ packages/vars/vignettes/vars.pdf

Ran, J., Voon, J.P. and Li, G. (2010), "How do oil price shocks affect a small non-oil producing economy? Evidence from Hong Kong", Pacific Economic Review, Vol. 15 No. 2, pp. 263-280. available at: https://doi.org/10.1111/j.1468-0106.2010.00501.x

Rana, R.H. and Hashmi, R. (2015), "The determinants of worker remittance in terms of foreign factors: the case of Bangladesh", Studies in Business and Economics, Vol. 10 No. 3, pp. 81-93, available at: https://doi.org/10.1515/sbe-2015-0038

Ratha, D. and Mohapatra, S. (2009), "Revised outlook for remittance flows 2009-2011: remittances expected to fall by 5 to 8 per cent in 2009", Migration and Development Brief, World Bank, N. 48018, March, available at: https://search.oecd.org/dev/americas/42825162.pdf.

Singh, R.J., Lee, K. and Haacker, M. (2009), "Determinants and macroeconomic impact of remittances in Sub-Saharan Africa”, working paper, 09/216, October, International Monetary Fund, available at: https://doi.org/10.5089/9781451873634.001

Sonmez, S. (2016), “The macroeconomic response to oil price shocks from 1970-2013”, Dissertation, The New School, available at: https://pqdtopen.proquest.com/doc/1797412642.html?FMT=AI

Vargas-Silva, C.I. (2006), "Determinants and consequences of workers' remittances", "Dissertation", Western Michigan University, available at: https://scholarworks.wmich.edu/dissertations/1000

Veeramoothoo, S. (2009), "Macroeconomic determinants of worker remittances to Latin American and the Caribbean countries", Honors Projects in Economics, Paper 10, Bryant University, available at: https://digitalcommons.bryant.edu/honors_economics/10 


\section{REPS}

\section{Further reading}

Elhamma, I. (2016), "Linking remittances with financial development and institutions: a study from selected MENA countries", working paper, halshs-01655353, HAL, available at: https://halshs. archives-ouvertes.fr/halshs-01655353

Lueth, E. and Marta, R.A. (2007), "Are workers remittances a hedge against macroeconomic shocks? The case of Sri Lanka”, Working paper, 07/22 February, International Monetary Fund, available at: www.imf.org/external/pubs/ft/wp/2007/wp0722.pdf

Raissi, M. and Mohaddes, K. (2011), "Oil prices, external income, and growth; lessons from Jordan", Working paper, 11/291, International Monetary Fund, available at: https://ideas.repec.org/p/imf/ imfwpa/11-291.html

\section{Corresponding author}

Mohamed Samir Abdalla Zahran can be contacted at: mohamed.zahran@commerce.menofia.edu.eg

For instructions on how to order reprints of this article, please visit our website: 